\title{
A NEW SPECIES, KEY TO FEMALES, AND DISTRIBUTION RECORDS FOR HETEROTARSONEMUS (ACARI: TARSONEMIDAE)
}

\author{
Robert L. Smiley ${ }^{1}$ and John C. Moser ${ }^{2}$ \\ 1. Systematic Entomology Laboratory, Agricultural Research Service, USDA, Beltsville, MD 20705 \\ 2. Southern Forest Experiment Station, Forest Service, USDA, Pineville, LA 71360
}

\begin{abstract}
Heterotarsonemus hajekae, new species is described and illustrated. A key to the females of Heterotarsonemus and a table on the distributions, localities, and hosts for all known species are included.
\end{abstract}

\section{INTRODUCTION}

Heterotarsonemus is a genus of mites whose biolJgy may or may not be closely tied to that of the bark beetles on which the females are phoretic. Most species have been discovered by collecting phoretic females from bodies of adult bark beetles caught in pheromone traps or reared from infested trees. Larvae and males of $H$. bicornis Lindquist and $H$. lindquist $i$ Smiley have also been located in galleries of their respective bark beetle hosts. Lindquist (1970) proposed that they usually exist in galleries with other species of the mite genus Tarsonemus. This is true for $H$. lindquisti but the relationship (if any) is unclear. When associated with the southern pine bark beetles Dendroctonus and Ips spp., $\boldsymbol{H}$. lindquisti occurs with three species of Tarsonemus: $T$. subcorticalis Lindquist, $T$. ips Lindquist, and $T$. krantzi Smiley \& Moser. The latter two feed on and vector a bluestain disease of Pinus spp., Ceratocystis minor (Hedgcock); phoretic females carry the ascospores in sporothecae under tergite 1 (Moser 1985).

Heterotarsonemus lindquisti has a small pharyngeal pump similar to those of Tarsonemus spp. This suggests that it is not parasitic and that it may be fungivorous like Tarsonemus spp. Species in another tarsonemid genus, Iponemus, have large pharyngeal pumps and parasitize bark beetle eggs. One possible fungus host is Trichoderma sp. or spp. whose spores are often seen on the $H$. lindquisti larvae taken from galleries of Dendroctonus frontalis Zimmermann. Tri- choderma is a green fungus that is ubiquitous under bark of pines infested with $D$. frontalis, but it is not known if the fungus is toxic to the tree. There is no reason to believe that $H$. lindquisti feeds on Ceratocystis minor because the mite seems to be equally common in both bluestain and bluestain-free populations of $D$. frontalis, and because the ascospores of $C$. minor have never been seen on larvae or adults of $H$. lindquisti.

The purpose of this paper is to summarize the existing information on the identification and biology of Heterotarsonemus, as well as to describe a new species that may have some relationship to the dutch elm disease, Ceratocystis ulmi (Buisman) C. Moreau.

We cannot be certain of the taxonomic status of $H$. egregius Livshitz, Mitrofanov, and Sharonov which Lindquist (personal communication 1984) considers to be a member of the genus Tarsonemus. The species apparently is not associated with bark beetles. Although there are obvious discrepancies on the illustrations of leg I of $H$. egregius, there are other illustrated morphological structures that show affinity to Heterotarsonemus. We prefer to retain this species as originally assigned until specimens can be obtained for study.

Some of the hosts and localities used here in Table 1 have been taken from Lindquist (1970) and Moser and Roton (1971). The terminology of Lindquist and Smiley (1978) and Emmanouel and Smiley (in press) is used for the taxonomic description. All measurements given are in microns. 
Table 1. Distribution, locality and host association 1

\begin{tabular}{|c|c|c|c|c|c|}
\hline Heterotarsonemus & Country & Locality & Phoretic host & Plant host & Reference \\
\hline bicornis & USA & $\begin{array}{l}\text { California } \\
\text { Colorado }\end{array}$ & $\begin{array}{l}\text { Ips emarginatus } \\
\text { Dendroctonus ponderosae }\end{array}$ & $\begin{array}{l}\text { Pinus jeffreyi } \\
\text { Pinus ponderosae }\end{array}$ & $\begin{array}{l}\text { Lindquist } 1970 \\
\text { Lindquist } 1970\end{array}$ \\
\hline coleopterorum & $\begin{array}{l}\text { Germany } \\
\text { Poland }\end{array}$ & $\begin{array}{l}\text { Erlangen } \\
\text { Torun } \\
\text { Siemianowice } \\
\text { Torun }\end{array}$ & $\begin{array}{l}\text { Pityogenes bidentatus } \\
\text { Pityogenes bidentatus } \\
\text { Pityogenes chalcographus } \\
\text { Crypturgus pusillus }\end{array}$ & $\begin{array}{l}\text { Pinus sylvestris? } \\
\text { Pinus sylvestris } \\
\text { Picea spp. } \\
\text { Picea abies }\end{array}$ & $\begin{array}{l}\text { Schaarschmidt } 1959 \\
\text { Wisniewski, pers. comm. } \\
\text { Wisniewski, pers. comm. } \\
\text { Wisniewski, pers. comm. }\end{array}$ \\
\hline egregius & USSR & Crimea & & Myrtus communis & Livshitz et al. 1982 \\
\hline hajekae n. sp. & USA & $\begin{array}{l}\text { Riverside, } \\
\text { California }\end{array}$ & Scolytus multistriatus & Ulmus pumila & \\
\hline \multirow[t]{2}{*}{ lindquisti } & $\begin{array}{l}\text { North and } \\
\text { Central } \\
\text { America }\end{array}$ & & $\begin{array}{l}\text { Perhaps all pine-attacking } \\
\text { Dendroctonus and Ips } \\
\text { species (as well } \\
\text { certain coleopterous and } \\
\text { hymenopterous associates) }\end{array}$ & Pinus spp. & $\begin{array}{l}\text { Lindquist } 1970 \\
\text { Moser, pers. comm. } \\
\text { Moser \& Roton } 1971 \\
\text { Smiley } 1969\end{array}$ \\
\hline & Sweden & Uppsala & Ips typographus & Picea abies & Moser, pers. comm. \\
\hline milleri & USA & $\begin{array}{l}\text { Marion } \\
\text { County, Ohio }\end{array}$ & Scolytus miltistriatus & Ulmus americana & Smiley \& Moser 1974 \\
\hline nakaharai & USA & $\begin{array}{l}\text { Grand } \\
\text { Canyon, } \\
\text { Arizona }\end{array}$ & Ips knausi & Pinus ponderosa & Smiley \& Moser 1974 \\
\hline
\end{tabular}

Key to Females of Heterotarsonemus

1. Anterolateral margin of propodosomal shield (Fig. 6) without conspicuous subtriangular projection behind each stigmata . . . . . . . . . . . .

- Anterolateral margin of propodosomal shield (Fig. 7) with conspicuous subtriangular projection behind each stigmata ........ bicornis Lindquist

2. Ventrocaudal or intertrochanteral lobe of metapodosomal venter (Figs. 1, 2, \& 3) broadly rounded or semicircular shaped, wider than long......3

- Ventrocaudal or intertrochanteral lobe of metapodosomal venter (Fig. 5) narrowly rounded or semicircular shaped, almost pointed; about long as wide ......... coleopterorum (Schaarschmidt)

3. Posterior dorsal margins of tergites II, III, and IV (Fig. 1) smooth; setae 2c stout or slender . . . . . 4

- Posterior dorsal margins of tergites II, III, and IV (Fig. 4) crenulate; setae 2c slender . .hajekae $\mathrm{n}$. sp.

4. Vertical seta on dorsal propodosoma (Figs. $1 \& 2$ ) more than half length of scapular seta; subterminal seta of leg IV longer or about same length of femurogenu IV (Figs. $8 \& 10) \ldots \ldots \ldots \ldots \ldots$

- Vertical seta on dorsal propodosoma (Fig. 6) less than half length of scapular seta; subterminal seta of leg IV shorter than length of femurogenu IV (Fig. 9) ............ nakaharai Smiley \& Moser

5 Subterminal seta (Fig. 8) of leg IV about same length of Leg IV; flange on femur II elongate
(Figs. $1 \& 11$ ) or subtriangular shaped (Fig. 12) . .6 - Subterminal seta (Fig. 10) of leg IV longer than leg IV; flange on femur II truncate (Fig. 13) ........ ................. milleri Smiley \& Moser 6. Flange on femur II large and elongate (Fig. 1 \& $11)$, setae $f$ and $e$ not equal in length ........... ...................... Lindquisti Smiley

- Flange on femur II small and subtriangular (Fig. 12) seta $2 a$ slender; setae $f$ and $e$ about equal in length ....... egregius Livshitz, Mitrofanov \& Sharonov

Heterotarsonemus hajekae Smiley and Moser, n. sp. (Figs. 2-4)

DIAGNOSIS - This species is distinctive from all other species in the genus in having crenulated margins posteriorly on dorsal tergites II, III, and IV. It can be recognized by the dorsal and ventral hysterosoma being covered with extremely small punctations, by the small longitudinal striations on dorsal tergite II, and by setae $1 \mathrm{a}, 2 \mathrm{a}, 3 \mathrm{a}$, and $3 \mathrm{~b}$ being extremely short and slender.

HOLOTYPE FEMALE - U.S. National Museum of Natural History - Body 213 (205-213) long and 112 (110-112) wide.

GNATHOSOMA - 29 (27-29) long and 26 (24-26) wide, with anterolateral simple setae about same length as ventral setae. Palpi approximate, directed anteromedially. Cheliceral stylets short, needlelike. 


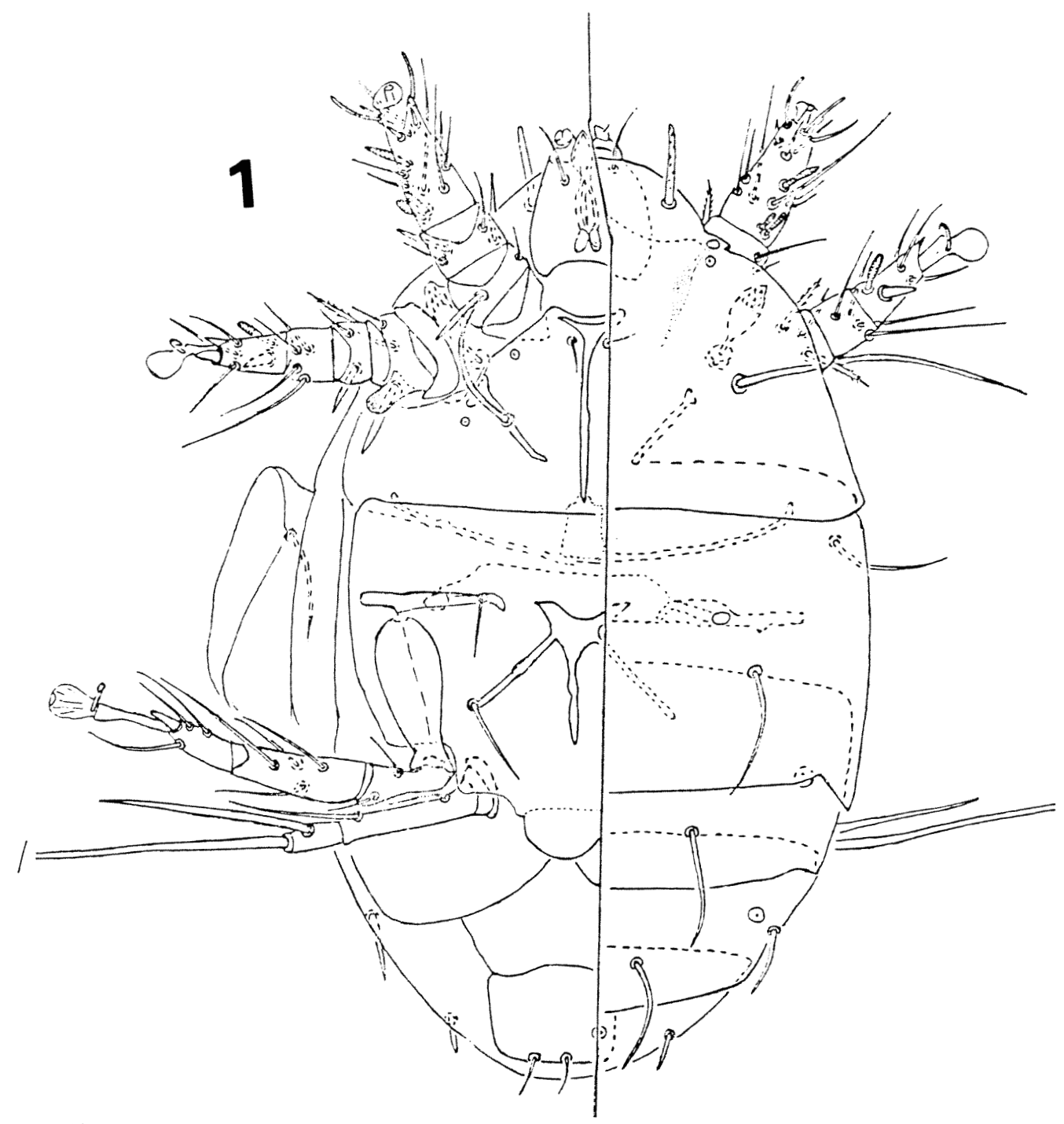

Fig. 1. Heterotarsonemus lindquisti Smiley, female, dorsal (right) and ventral (left) view.

Pharynx sclerotized, with wishbone-shaped walls; with a pair of glandular structures near its posterior extremity as figured.

IDIOSOMA - Oval. Length: 205 (221-227), width 112 (110-112) (4 specimens). Prodorsal shield ornamented with extremely small punctations; subtriangular as figured. Bothridal setae capitate, finely spiculate. Stigmata protruding slightly from edges of shield. Tracheal trunks indistinct. Dorsal setation as follows: $v_{1}$ : 31 (19-31); sc2: 51 (44-57); $c_{1}: 19$ (19-20); c2: 25 (19-31); d: 25 (19-31); e: 19 (17-19); f: 25 (12-25); h: 19 (12-19). Distance between $c_{1}-c_{2}$ and $c_{1}$ d: 76 (70-76) and 82 (70-82) respectively. Apodeme I short, converging with anteromedian apodeme; apodeme II stout and longer, not converging with anteromedian apodeme; anteromedian apodeme con- verging with transverse apodeme. Apodeme III more developed than apodeme IV. Posteromedian apodeme forklike anteriorly, uniting with apodeme IV. Coxal setae 1a: 6 (5-6); 2a: $6(5-6)$ in length, inserted directly above each apodeme. Coxal setae $3 a: 6(5-6)$ in length, inserted in front and near anterior extremities of apodeme III; $3 \mathrm{~b} 6$ in length, inserted on and towards posterior end of apodeme IV. Ventrocaudal lobe between leg IV 25 (24-25) wide and 19 (18-19) long. Setae ps 12 (12-19) long. Leg I and II subequal in length, both shorter than legs III. Setation respectively on femur, genu, and tibiotarsus of leg I: $3-4-4(3)+$ 4(1), leg II: 3-3-4-5(1); leg III: $1+3-4-4$. Leg II with Gea slender. Tav of legs II - III long and stout. Leg IV slender, not extending beyond posterolateral edge of idiosoma, femurogenu about $2 \mathrm{x}$ as long as tibiotarsus. 


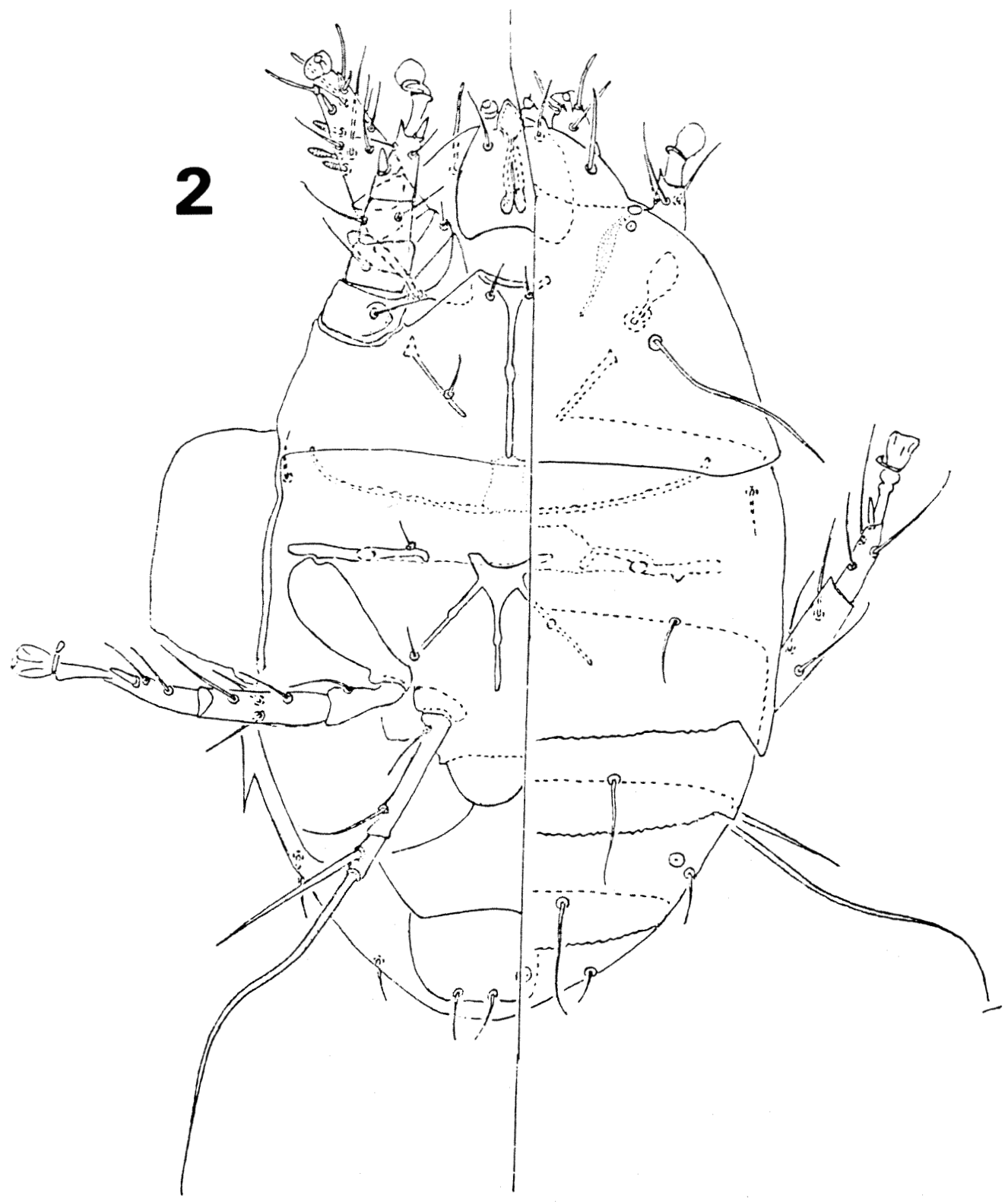

Fig. 2. Heterotarsonemus hajekae, n. sp., female, dorsal and ventral view.

Distal (femoral) seta longer than proximal femoral seta 11 (7-11) and 9 (7-9) respectively. Terminal (tarsal) seta about $3 x$ as long as subterminal (tibial) seta: 67 (43-67) and 25 (15-25) respectively.

TYPE MATERIAL - Female taken from galleries of Scolytus multistriatus in Siberian Elm, Riverside, California, January 1978 by L.A. Brown deposited in the U.S. National Museum Natural History. Paratype 3 females with the above data. One paratype deposited in the U.S. National Museum of Natural History and two deposited in the USDA Forest Service collection at Pineville, LA. The male is not known.

ETYMOLOGY - The species is named for Ann E. Hajek, University of California, Berkeley who discovered this mite in connection with her thesis (Hajek, 1980).

\section{ACKNOWLEDGMENTS}

We are indebted to Dr. Manya B. Stoetzel, Systematic Entomology Laboratory, ARS, USDA, Beltsville, Maryland for taking the photomicrographs used 

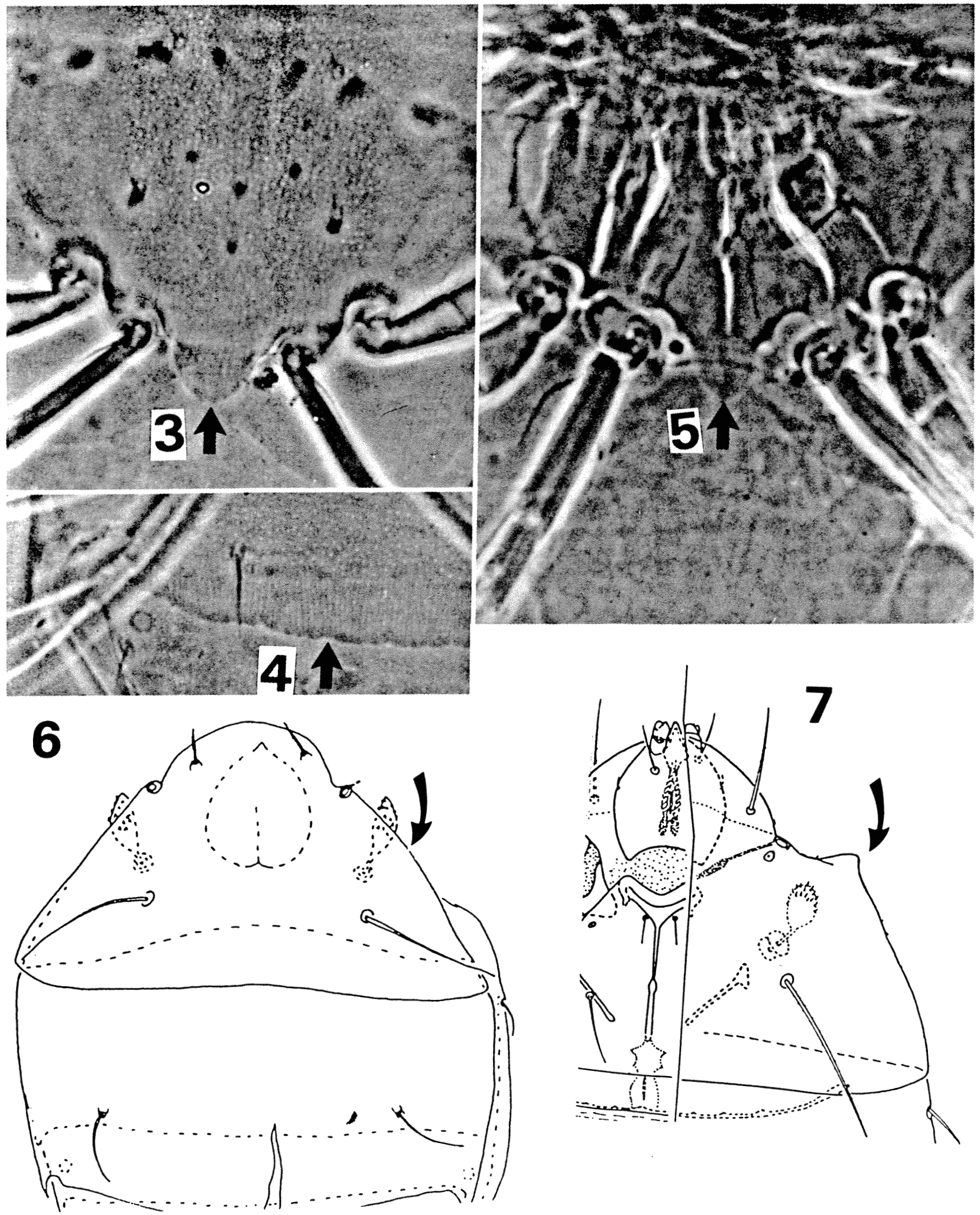

Fig. 3-4. Heterotarsonemus hajekae, n. sp. (female) ventral view. 3, ventral region of metapodosoma; 4, tergite III dorsal hysterosoma. Fig. 5. Heterotarsonemus coleopterorum (Schaarschmidt), female, ventral region of metapodosoma. Fig. 6. Heterotarsonemus nakaharai Smiley \& Moser, female, dorsal idiosoma. Fig. 7. Heterotarsonemus bicornis Lindquist, female, dorsal (right) and ventral (left) anterior idiosoma. 

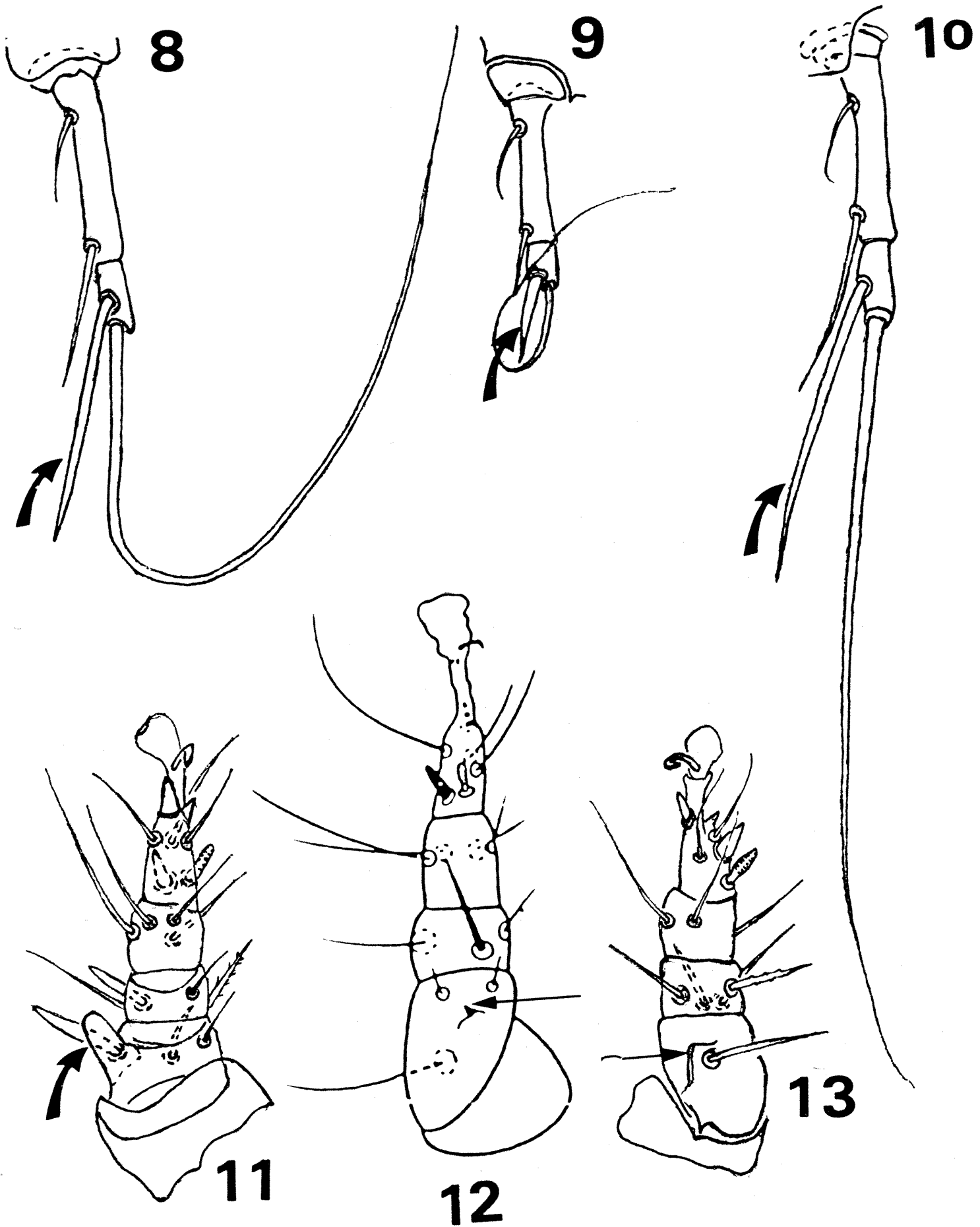

Fig. 8. Heterotarsonemus lindquisti Smiley, female, subapical seta leg IV. Fig. 9. Heterotarsonemus nakaharai Smiley \& Moser, female, subapical seta leg IV. Fig. 10. Heterotarsonemus milleri Smiley \& Moser, female, subapical leg IV. Fig. 11. Heterotarsonemus lindquisti Smiley, female, flange leg I. Fig. 12. Heterotarsonemus egregius Livshits, Mitrofanov \& Sharonov, female, flange leg I. Fig. 13. Heterotarsonemus milleri Smiley \& Moser, female, flange leg I. 
in this study. We extend special appreciation to Dr. Gisela Rack, Zoologisches Institut und Zoologisches Museum, Universitat Hamburg, Hamburg, Germany for loaning the type of Heterotarsonemus coleopterorum (Schaarschmidt). Also we thank Dr. Mercedes Delfinado-Baker, Department of Entomology, University of Maryland, College Park, Maryland and Dr. Robert W. Poole, Systematic Entomology Laboratory, c/o U.S. National Museum Natural History, Washington, D.C. for reviewing this manuscript.

Special appreciation is extended to Ms. Donna Oliveria, Southern Forest Experiment Station, USDA, Pineville, Louisiana for typing this manuscript.

\section{REFERENCES}

Emanoueol, N.G. and R.L. Smiley. 1985. Two new species of the family Tarsonemidae (Acari: Prostigmata) from Greece. Entomol. Hellenica (in press).

Hajek, Ann E. 1980. Factors influencing Scolytus multistriatus (Marsham) (Coleoptera: Scolytidae) populations in California. Unpublished thesis. $101 \mathrm{pp}$. University of California, Berkeley.

Lindquist, E.E. 1970. Review of the genus Heterotar- sonemus (Acarina: Tarsonemidae). Can. Entomol. 102: 812-829.

Lindquist, E.E. and R.L. Smiley. 1978. Acaronemus, a new genus proposed for tarsonemid mites (Acari: Prostigmata) predaceous on tetranychoid mite eggs. Can. Entomol. 110: 665-662.

Livshitz, I.Z., V.I. Mitrofanov, and A.A. Sharonov. 1982. New species of mites (Acariformes, Tarsonemidae) from Crimea. Zool. Zh. 61 (4): 610-613.

Moser, J.C. and L.M. Roton. 1971. Mites associated with southern pine bark beetles in Allen Parish, Louisiana. Can. Entomol. 103: 1775-1798.

Moser, J.C. 1985. Use of sporothecae by phoretic Tarsonemus mites to transport ascospores of coniferous bluestain fungi. Trans. Br. Mycolog. Soc. 84: 750-753.

Schaarschmidt. L. 1959. Systematik und Ökologie der Tarsonemiden. Beitr. Syst. Okol. mitteleur. Acarina 1, Abschn. 5: 713-823.

Smiley, R.L. 1969. Further studies on the Tarsonemidae, II (Acarina). Proc. Entomol. Soc. Wash. 71: 218-229.

Smiley, R.L. and J.C. Moser. 1974. New tarsonemids associated with bark beetles (Acarina: Tarsonemidae). Ann. Entomol. Soc. Amer. 67 (4): 639-665. 
